\title{
CDKN2B Gene
}

National Cancer Institute

\section{Source}

National Cancer Institute. CDKN2B Gene. NCI Thesaurus. Code C18323.

This gene is involved in cell cycle regulation and arrest. 